\title{
Institutional approach to classification of sustainable digital technologies in service logistics
}

\author{
Roman Okorokov ${ }^{1,}{ }^{*}$, Anna Timofeeva ${ }^{1}$, Evgeniya Filyanina $^{1}$, and Mohamed Lamine \\ Benchabane ${ }^{2}$ \\ ${ }^{1}$ Higher School of Industrial Management and Economics, Institute of Industrial Management, \\ Economics and Trade, Peter the Great St. Petersburg Polytechnic University, 195251 St. Petersburg, \\ Russia \\ ${ }^{2}$ Yahia Fares, Université de Medea, Algeria
}

\begin{abstract}
Industrial revolution is the trigger of the growing demand from households for consumer services, and from the other institutional units for services improving the quality of production processes. The quality of services is the factor of the competitiveness of objects at different levels of the country's economy. In turn, logistics mediates all the processes of building a service as an intangible product. The nowadays trend of digitalization of all economic spheres is particularly relevant for logistics of the service sector. The article shows the direct and cyclical inverse role of the service sector in the modern economy in terms of its impact on the competitiveness of objects of different levels. The classification of services relevant to the research goals is given. Features of factors of competitiveness of non-material production are revealed. The role of logistics forming the competitiveness of enterprises in the non-material sphere is shown. Criteria for the classification of digital technologies of industry 4.0 in logistics of the service sector are proposed. Digital technologies involved in the sector of consumer and non-consumer services of material impact on property are presented and justified.
\end{abstract}

\section{Introduction}

The country's economy can be represented by various industries that are grouped into three main sectors: agriculture, industry, and services. The current technological structure of the post-industrial economy is a result of the increased influence of the service sector in the formation of gross output in the world, which is primarily true for developed economies $[1,2]$. According to the World Bank, the average value added of the service sector in the world as a percentage of GDP in 2019 was $54.4 \%$, for the European Union $-63.82 \%$. Sustainable growth of this sector was initially promoted by the factors associated with industrial production, among which the following: the agrarian revolution of 16-18 century, the market of goods formed by that time and the primitive accumulation of merchants and entrepreneurs capital, which led to the industrial revolution. Since the first industrial

\footnotetext{
*Corresponding author: roman_okorokov@spbstu.ru
} 
revolution of the late 18th and early 19th century, with a certain degree of objectivity based on specific indicators one can talk about the introduction of innovations into production and economic sector that increased the efficiency of production and further capital accumulation, growth of welfare of the population and the share of non-working time [3]. These effects of industrial revolutions, in turn, have stimulated the demand from households for consumer services, and from the other institutional units for services to organize and improve the quality of production processes.

Services as an object of economic value created for consumption are the intangible products having the properties of impalpability, inseparability from the source of provision, lack of ownership, impermanence of quality and non-preservation. A large number of types of services are caused by the steadily growing needs of the population [4]. These needs are manifested in the increase in demand for long-existing services as well as in demand for innovations in this area. In this regard, the various classifications of services based on criteria as functional purpose, distribution area, presentation conditions, nature of consumption, etc. are presented in research reports as well as in reports of international organizations such as the United Nations, the World Trade Association and the Organization for Economic Cooperation and Development [5, 6].

The purpose of the article is to show the role of service sector in modern economy from the point of view of its influence on the competitiveness of objects of different levels and to propose criteria for the classification of digital technologies of Industry 4.0 in logistics services.

\section{Materials and Methods}

Materials for the conducted research include classifications of services and statistical data of the World Economic Forum. For the purposes of this study the services are classified in terms of the service object and the consumer services are highlighted such as intangible products intended for the end user and households. The non-consumer services are also highlighted, namely, intangible products that target non-financial and financial corporations, non-profit institutions and the government sector. The consumer and nonconsumer services should be further classified in terms of the properties of material and non-material impact (Table 1) thus complementing the classification of services proposed by C. Lovelock [7], the founder of the theory of service marketing. The services related to property and intangible assets are thus aimed at both households and enterprises of various organizational and legal forms and forms of ownership.

At the present, the growing importance of the service sector is determined by increasing competition in the national and international markets. The provision of relevant services and their high quality is a factor of competitiveness at different levels: global, macroeconomic and microeconomic. Consequently, the services increase the competitiveness of countries on the world stage as well as the enterprises and goods in the national and international markets. According to the World Economic Forum's Global Competitiveness Index, the services directly or indirectly belong to all three of its subindexes: basic conditions, performance factors and innovation factors. Such enlarged subindex factors as "Efficiency of commodity and service markets", "Development of the financial market", "Higher education and training", "Infrastructure", "Health and primary education", "Business maturity", "Innovation" contain many indicators of the service sector [8]. 
Table 1. Classification of consumer and non-consumer services in terms of the properties of material and non-material impact.

\begin{tabular}{|c|c|c|c|}
\hline & & \multicolumn{2}{|c|}{ Service objects } \\
\hline & & Household & Other institutional units \\
\hline & & Consumer services & Non-consumer services \\
\hline \multirow{3}{*}{ 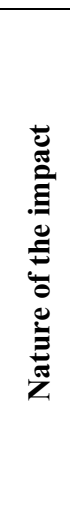 } & \multirow[b]{2}{*}{$\begin{array}{l}\text { Material } \\
\text { impact }\end{array}$} & \multicolumn{2}{|c|}{$\begin{array}{l}\text { Property services: transportation of items, repair and security of } \\
\text { items, warehousing and storage, cleaning, dry cleaning, waste } \\
\text { management, care of gardens and parks }\end{array}$} \\
\hline & & $\begin{array}{l}\text { Services aimed at a person as an } \\
\text { individual: transport, medicine, } \\
\text { hotel business, catering, beauty } \\
\text { salons, sports clubs, hairdressers }\end{array}$ & $\begin{array}{l}\text { Services aimed at a person } \\
\text { who is a member of a legal } \\
\text { entity: transport, medicine, } \\
\text { hotel business, public } \\
\text { catering. }\end{array}$ \\
\hline & $\begin{array}{l}\text { Non-material } \\
\text { impact }\end{array}$ & $\begin{array}{l}\text { Services aimed at the inner world of } \\
\text { a person: entertainment industry, } \\
\text { consulting services, education, } \\
\text { psychoanalytic services }\end{array}$ & $\begin{array}{l}\text { Services related to intangible } \\
\text { assets: accounting services, } \\
\text { banking services, } \\
\text { information processing, } \\
\text { insurance services, legal } \\
\text { services }\end{array}$ \\
\hline
\end{tabular}

\section{Results}

The company's competitiveness is influenced by external and internal factors. The external factors and indicators can be classified according to the method of the World Economic Forum. The following internal factors of the enterprise competitiveness were identified in the research [9] such as product concept, quality in comparison with market leaders, price level, financial resources of the enterprise, commercial methods and means of trade, aftersale service, international activity of the enterprise and presale preparation. The factors of the enterprise competitiveness are closely intertwined with the competitive factors of the tangible or intangible product, which are affected in turn by the quality of the value chain processes. The M. Porter's model of the value chain (see Fig. 1) is represented by the main activities (incoming deliveries, production, outgoing deliveries, marketing and sales, service) and auxiliary activities (firm infrastructure, personnel management, technological development, logistics).

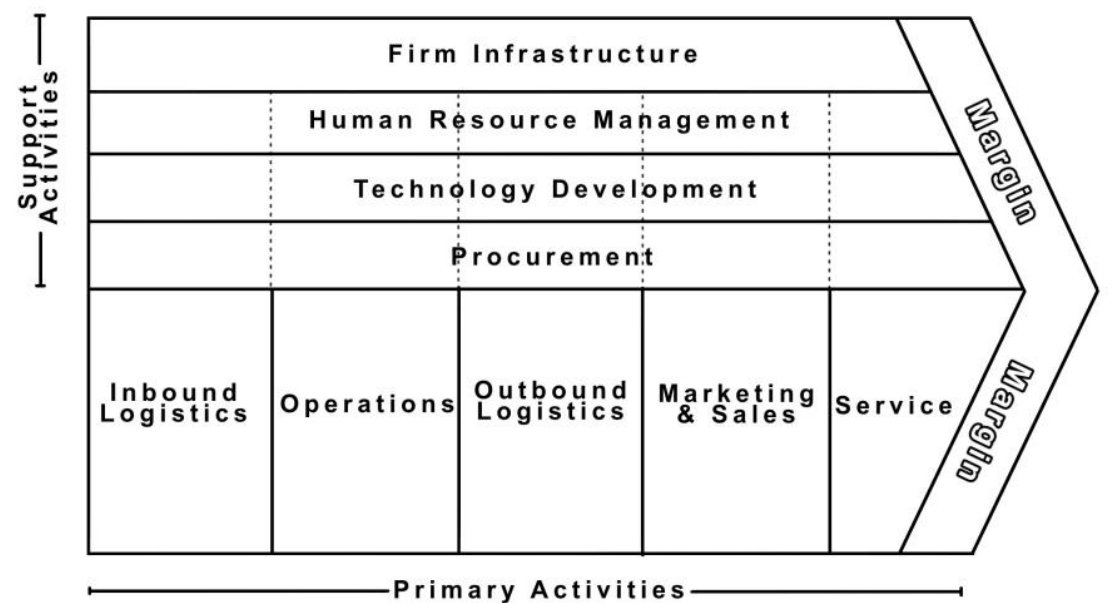

Fig. 1. M. Porter's Value Chain Model [10]. 
In the case of intangible production or manufacture in the service sector the M. Porter's value chain is varied by combining "Transactions (production)" and "Outgoing deliveries" in one element according to the property of services such as "Inseparability from the source». Thus, the factors of competitiveness of intangible production differ from the factors of competitiveness of material production at the level of elements of the value chain [11]. It should be also noted that the factors of competitiveness and the objects of their influence may coincide in the case of the enlarged classification: the "Financial services" factor effects on such object as "Educational services", but they are both represented by the same definitions of "Services" or "Consumer services". Therefore, it is necessary to understand the cyclical impact of the service sector on other sectors of the economy and factors of the competitiveness as well as the actual return impact.

The factors of competitiveness of the intangible production enterprises that are provided by the logistics and supply chain management processes correspond to their specific functions. The definition of "Logistics" includes the micro-level processes of the enterprise. The definition of "Supply chain management" refers to the processes that go beyond the enterprise and relate to the integration and interaction of organizations. Logistics combines the processes within the enterprise being the direction of tactical activity within the supply chain strategy. Logistics can be outsourced to the third parties [12]. The definition of "Logistics" can be defined as the company's activity to manage the internal material, financial and information flows in order to optimize them. This ensures maximum efficiency of the interaction of these flows in a certain balance of the related effects and costs.

Supply chain management concerns strategic management and includes logistics, planning, working with external partners and contractors [13]. The definition of "Supply chain management" can be defined as the activity to manage the resource flows in the supply, production and sales processes starting from the primary level (organization) in the value chain up to the end user. The goal of such activity is to achieve the high level of competitiveness of the enterprise and the entire supply chain in the market. The functions of logistics and supply chain management coincide in a generalized form, which can be formulated as follows: managing the movement of raw materials and the finished products later in the direction of the market.

The specific functions of logistics and supply chain management are discussed below. In the case of logistics these functions include management in the following areas or facilities: procurement, warehouse, transport, inventory distribution and foreign economic activity. Supply chain management is characterized by such areas or objects: order fulfillment, production processes, supply, product development and commercialization, returnable material flows, customer relationships, customer service and demand. In that way logistics is aimed at the physical implementation of the material flow management while the supply chain management is aimed at finding the balance between needs and supplies throughout the value chain for the consumer (see Fig. 2).

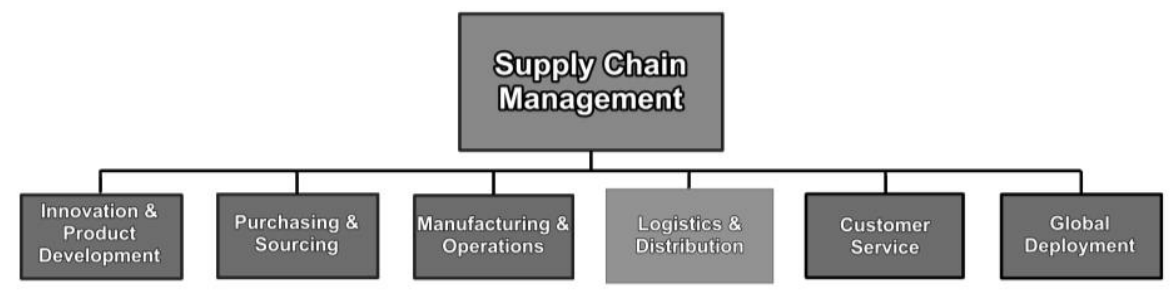

Fig. 2. The concepts that are covered by Supply Chain Management [14]. 
The definition of "Logistics services" is defined by the services provided by logistics companies. The types of logistics services are allocated according to the logistics functions. The transport logistics services are aimed to form the route of transport, its types and to determine the optimal time for moving goods. The warehouse logistics services deal with the issue of establishing the territory of goods storage, the room size and the temperature regime. The sales or purchasing logistics services are based on the transportation of goods to the consumer in a certain time frame [15].

For the purposes of the study it is necessary to distinguish the difference between the definitions of "Logistics services" and "Service logistics", "Maintaining service logistics" as well as to differentiate the definitions of services and maintaining service for the supply chain management processes. Many sources equate these definitions. However it seems correct to clarify their content defining the "Maintaining service" as an additional service to the main product or service. The complex nature of the tangible or intangible product in many sectors of the economy allows separating the definitions of "Services" and "Maintaining service". The maintain service includes such activities as analyzing the customer's order, optimizing the terms of service, product sales or after-sales service.

The definitions of "Service logistics" and "Maintaining service logistics" are defined in accordance with the specific features of the definitions of "Services" and "Maintaining service". The definition of "Logistics services" is the logistics within the company of the services sector relating to the key activity of the company. Also, the "Logistics services" is the activity of a company belonging to the service sector to manage the main internal material, financial and information flows. The purpose of that is to achieve the maximum efficiency of interaction of these flows in a certain balance of related effects and costs. The definition of "Service logistics" includes the provision of the main service in the case of the service sector company. The definition of "Maintaining service logistics" is the logistics of maintenance within the service sector company connected with the tangible or intangible production.

From the point of view of strategic management the definition of "Supply chain management" can be applied to the companies maintaining services to tangible production as well as the companies providing basic and auxiliary services or maintaining services of the intangible production. It does not make sense to highlight the difference between supply chain management in services and maintaining service due to the higher level of management in this case. It is impractical to manage the company's competitiveness by separating the main and additional services. Therefore, the supply chain management in services and maintaining services is the identical definition [16].

\section{Discussion}

Many countries have entered an unspoken "race" to digitalize their national economies in order to expand the market positions. The world community coordinates the activities to build the digital social and economic systems trying to give the digitalization a positive direction [17]. The global movement towards the digitalization is also transforming the logistics industry. Digitalization is changing the formats of delivery, methods of movement of goods and control processes. It is not enough now for companies to produce high-quality products in order to become the "race" leader, they also need to invest in digital technologies [18].

Digitalization of the logistics refers both to the logistics services provided to the intangible production and the logistics in the services and maintaining service sector directly. In the case of logistics services, the digital technologies cover the digitalization of cargo transportation. It includes intelligent systems for cargo managing and tracking at all stages of transportation; technologies that do not use human labor; full automation of 
document flow ensuring transportation within the country and the international cross-border traffic with rapid customs clearance of goods [19].

Digitalization of the service logistics includes technologies aimed at collecting and processing the information about customers and processes as well as analyzing and presenting this information in order to improve the quality of services and maintaining service [20]. The goals of digitalization of logistics include the formation of a reliable infrastructure that allows to process and store the large amount of data based on information and telecommunications technologies. Such activities provide the effects of increasing the revenue and reducing the cost of the logistics system.

The tasks and activities of digitalization of logistics in the service sector depend largely on the specific industry application of technologies. The common tasks include the automation and improving the efficiency of resource movement; building the system for logistics costs analysis; production, transportation and demand forecasting; reducing the service delivery time and the level of insurance reserves [21].

The classification of digital technologies in the service sector can be presented by the allocation of service objects and the nature of the impact (Table 1). Thus, the digital technologies of material and non-material impact are highlighted aimed at households and involved in the provision of consumer services. Also, the digital technologies increasing the efficiency of non-consumer services implementation for the other institutional units can be highlighted.

The classification of digital technologies in the services sector based on the allocation of institutional units and the nature of impacts is appropriate for use in the analysis of the processes of building the digital infrastructure of the country's economy, identification of the potential for technologies implementation and assessment of the current results. The justification for this type of classification is based on the structure the country's macroeconomic indicators, namely, the system of national accounts unified in most countries of the world. The system of national accounts is based on the results of country's economic activities in terms of the institutional units.

The digital technologies used for the implementation of consumer and non-consumer services of material impact on property include directly the technologies of digitalization of transport, warehousing and storage. The important goal of digital logistics is to speed up constantly the delivery process, which is especially necessary in the service sector [22]. The cross-docking helps the offline retailers to achieve this goal. The cross-docking is the set of operations for reload and distribution shipments from heavy-duty vehicles to low-tonnage ones for delivery to stores. Herewith the processes of product turnover are accelerated due to the reduction in the storage time of orders in the warehouse.

The delivery is often carried out from the warehouse to the customer's address using the online shopping. The speed of order completion plays the important role in the supplier's competitiveness. In this case it is important to transfer all logistics to one 3PL (Third Party Logistics) operator on the principle of fulfillment - from receiving and processing the order to delivering to the client. The supplier ensures the delivery of the order in the shortest possible time following this principle.

The digital information platforms play the leading role in the digital economy. Today one of the most important trends in domestic logistics in the service sector is the transition from individual to platform solutions.

Local digital information platforms are used for planning the transportation process, organizing the interaction of different types of transport on the basis of transport hubs, cargo handling in warehouses. This allows significantly to reduce the time and financial costs of transport companies and their customers. More complex digital information platforms are used by so-called logistics intermediaries performing various service functions and managing individual competencies of production companies. The logistics 
intermediaries integrate all participants in the value chain; channels of organizations that supply goods or spare parts; consumers and individual sectors of the economy. The digital information platforms allow to solve the several tasks at once, while the individual programs and services cannot afford. Therefore, the logistics sector is becoming a powerful driver for the development and competitiveness of the individual companies and the entire industries in the global market in the digital age.

The digital logistics is directly related to the search for economic benefits as noted earlier. At the moment, a number of the most promising directions of the digitalization of transport can be highlighted: the transparency of movement (the ordered product can be tracked by geolocation throughout the entire supply chain); the impossibility of fuel theft, the misuse of working vehicles and the availability of the data for investigation of the occurred incident; integration of ERP systems; instant accounting of logistics warehouses, product containers or halls; robotization of warehouse systems; the autonomy of the transport [23].

Global population prefers increasingly online shopping because it is fast, high-quality and inexpensive. People no longer have to spend hours looking for the right product, going to all sorts of stores in the city since everything is online. However, every year online retailers suffer more and more losses on logistics. The cost of storing and delivering goods exceeds significantly the revenue.

The increase in demand and the high cost of storage and delivery leads to a new step in logistics services. The solution is the introduction of a new system of technological platform for warehouse activities and robotization of warehouses that exceeds human capabilities. The wearable devices play a key role in the transformation of digital logistics. Robots handle packaging, delivery, tracking, remote control and analysis. The inventory management eliminates the possibility of errors, accidents and so-called "human factor" using robotic systems. Thus, the efficiency of the service sector increases significantly. For example, Amazon has already managed to reduce the operating costs by $\$ 22 \mathrm{mln}$ thanks to robotics. At the same time, the company still has not implemented robots in all warehouses, when this happens the costs will be reduced by $\$ 800 \mathrm{mln}$ [24].

\section{Conclusions}

Based on the results of the study, the authors draw the following conclusions:

1. The competitiveness of the objects at different levels of the country's economy depends on many factors. The development of the service sector is one of the factors of competitiveness at different levels. The services are highlighted as the separate factor affecting the results of the economic systems. Also, the services and maintaining service are the integral part of the other elements forming the potential for the successful competition in the market. In particular, the services and maintaining service of some industries affect cyclically the quality of these services provided by other industries.

2. The logistics helps to improve the efficiency of interaction between the service sector and the other sectors of the economy combining all elements of the economy in one system. The improvement of logistics processes is based on the digital technologies.

3. The criteria for the classification of digital technologies in the logistics of the service sector are proposed. The scientific novelty is that the proposed classification based on the identification of institutional sectors as the object of influence, consumer and non-consumer services allows further identification of the potential for technology implementation and assessment of the current results of modernization and innovation processes. The basis for such classification is the structure of the country's macroeconomic indicators, namely, the system of national accounts. 
4. The digital technologies development is the fast and continuous process. Every day more and more companies are moving to digital technologies and automation increasing their potential to win in the competition. The successful example is contagious, so one can assume that in the near future a cumulative effect will work: companies being in the digital "race" will start copying each other which brings the service sector to a new level.

\section{References}

1. K.K. Robison, E.M. Crenshaw, Social Science Research 31(3), 334-363 (2002)

2. A. Breitenfellner, A. Hildebrandt, Monetary Policy \& the Economy 1, 110-135 (2006)

3. P. Bairoch, Journal of European Economic History 2, 269-310 (1982)

4. G.F. Anderson, P.S. Hussey, Health Affairs 19, 191-203 (2000)

5. M. Masdari, H. Khezri, Journal of Ambient Intelligence and Humanized Computing (2020) https://doi.org/10.1007/s12652-020-02441-w

6. T. Buganza, D. Trabucchi, E. Pellizzoni, Technology Analysis \& Strategic Management 32(1), 58-70 (2018)

7. C. Lovelock, Journal of Marketing 47, 9-20 (1983)

8. M. Marceta, S. Bojnec, Sciendo 53(1), 37-52 (2020)

9. E. Sysoeva, Economic science 12(73), 283-287 (2010)

10. Value Chain: A Conceptual Framework, http://accioneduca.org/admin/archivos/clases/material/value-chain_1564001043.pdf

11. H. Dzwigol, M. Dzwigol-Barosz, A. Kwilinski, International Journal of Entrepreneurship 24(1), 1-5 (2020)

12. C. Thies, K. Kieckhäfer, T.S. Spengler, Journal of Business Economics (2020) https://doi.org/10.1007/s11573-020-01004-x

13. I. Pustokhina, Bulletin of the State University of Management 4, 123-129 (2015)

14. Is Logistics the Same as Supply Chain Management? https://www.michiganstateuniversityonline.com/resources/supply-chain/is-logisticsthe-same-as-supply-chain-management/

15. MMLOGISTIK Homepage, https://www.mm-logistik.vogel.de/was-ist-logistik-40alles-zum-thema-digitalisierung-logistik-a-692722/

16. W. Kersten, M. Seiter, B. von See, N. Hackius, T. Maurer, Trends und Strategien in Logistik und Supply Chain Management - Chancen der digitalen Transformation (DVV Media Group GmbH, Hamburg, 2017)

17. R. Okorokov, A. Timofeeva, T. Kharlamova, IOP Conference Series: Materials Science and Engineering 497 (2019) https://doi.org/10.1088/1757-899X/497/1/012015

18. T. Kharlamova, N. Grashchenko, A. Timofeeva, R. Okorokov, IOP Conference Series: Materials Science and Engineering 497 (2019) https://doi.org/10.1088/1757-899X/ 497/1/012031

19. W. Delfmann, M. Hompel, W. Kersten, T. Schmidt, W. Stölzle, Logistik als Wissenschaft - zentrale Forschungsfragen in Zeiten der vierten industriellen Revolution: Positionspapier des Wissenschaftlichen Beirats der Bundesvereinigung Logistik (BVL e.V., Bremen, 2017)

20. A. Rudskoy, I. Ilin, Proceedings of the 33rd International Business Information Management Association Conference: Education Excellence and Innovation Management through Vision 2020 (IBIMA, Granada, Spain, 2019) 
21. S. Maydanova, I. Ilin, Proceedings of the 33rd International Business Information Management Association Conference, IBIMA 2019: Education Excellence and Innovation Management through Vision 2020 (IBIMA, Granada, Spain, 2019)

22. A.D. Borremans, I.M. Zaychenko, O.Y. Iliashenko, MATEC Web of Conferences 170 (2018) https://doi.org/ 10.1051/matecconf/201817001034

23. G.Silkina, IOP Conference Series: Materials Science and Engineering 497 (2019) https://doi.org/10.1088/1757-899X/497/1/012018

24. E-PEPPER Homepage, https://e-pepper.ru/news/kiva-robots-help-amazon-cutexpenses 